\title{
Translating Metonymies of the Incarcerated Female Self in Pasos bajo el agua/Steps Under Water, by Argentine Writer Alicia Kozameh'
}

\author{
Gabriela Luisa Yañez \\ gabriela.luisa.yanez@gmail.com \\ https://orcid.org/0000-0003-1946-3761 \\ Universidad Nacional de La Plata - Instituto de Investigaciones \\ en Humanidades y Ciencias Sociales (UNLP-CONICET)
}

\begin{abstract}
This paper analyzes the English translation of the Argentine testimonial narrative Pasos bajo el agua (1987), an account of the last military dictatorship in Argentina by Alicia Kozameh. The article proposes a case study that explores the evocative potential of metonymy in translation for repositioning female subjectivities across borders from a transnational feminist translation perspective. From a literary standpoint, metonymy is defined here as a figure of speech whereby a term is used to evoke a whole range of culture-bound associations closely connected with experience. The article's goal is twofold: (1) to look into the role of metonymy in the translated text for recreating and reconfiguring the network of complex power relations in the feminist text and (2) to examine the geopolitics of feminist translation and the power relations established in the translation of an Argentine Spanish-written text into English. This can be revealed by examining the translation of specific metonymies that display the incarcerated female condition in the source text. Results show that the evocative mechanisms of metonymy help to foreground gender relations and, therefore, require careful consideration in the translation of feminist texts from a transnational perspective.
\end{abstract}

Keywords: metonymy, translation, transnational feminism, testimonio, Alicia Kozameh.

Traducir las metonimias de la condición femenina encarcelada en Pasos bajo el agua/Steps Under Water, de la escritora argentina Alicia Kozameh

\section{Resumen}

Mediante un estudio de caso, este artículo aborda el potencial evocativo de la metonimia en la traducción para reposicionar las subjetividades femeninas en otra lengua y cultura desde una perspectiva transnacional de la traducción feminista. En el campo literario, la metonimia se define como una figura retórica mediante la cual un término se emplea para evocar una serie de asociaciones culturales que se encuentran íntimamente vinculadas a la experiencia. El artículo persigue dos objetivos: (1) analizar el rol de la metonimia en la traducción para observar la recreación y reconfiguración de

1 This paper is part of the project "Escrituras de minorias, ethos y (auto) traducción" (UNLP, H/825, 2017-2020). 
la compleja red de relaciones de poder en el texto feminista; y (2) examinar aspectos geopolíticos de la traducción en torno a las relaciones de poder instauradas en la traducción de un texto argentino escrito en español al inglés. Para ello, se estudia la traducción de metonimias específicas que revelan la condición femenina encarcelada en Pasos bajo el agua (1987), un relato testimonial sobre la última dictadura militar argentina escrito por Alicia Kozameh. Los resultados muestran que los mecanismos evocativos de la metonimia contribuyen a revelar las relaciones de género $\mathrm{y}$, por tanto, requieren especial consideración para la traducción de textos feministas desde una perspectiva transnacional.

Palabras clave: metonimia, traducción, feminismo transnacional, testimonio, Alicia Kozameh.

\section{Traduire les métonymies de la condition féminine incarcérée dans Pasos bajo el agua / Steps Under Water, de l'écrivaine argentine Alicia Kozameh}

\section{Résumé}

À travers une étude de cas, cet article expose la puissance évocatrice de la métonymie dans la traduction pour replacer les subjectivités féminines dans une autre langue-culture depuis une perspective transnationale de la traduction féministe. Dans le champ littéraire, la métonymie est définie comme une figure rhétorique par laquelle un terme est employé pour évoquer une série d'associations culturelles qui se trouvent intimement liées à l'expérience. L'article vise deux objectifs : (1) analyser le rôle de la métonymie dans la traduction à fin d'observer la recréation et la reconfiguration du complexe réseau de relations de pouvoir dans le texte féministe; et (2) examiner des aspects géopolitiques de la traduction autour des relations de pouvoir érigées dans la traduction d'un texte argentin écrit en espagnol vers l'anglais. Pour cela, nous étudions la traduction des métonymies spécifiques qui révèlent la condition féminine incarcérée dans Pasos bajo el agua (1987), un récit qui témoigne de la dernière dictature militaire argentine écrit par Alicia Kozameh. Les résultats mettent en évidence que les mécanismes évocateurs de la métonymie contribuent à révéler les relations de genre et, par conséquent, ils méritent d'être particulièrement considérés dans la traduction des textes féministes suivant une perspective transnationale.

Mots clés : métonymie, traduction, féminisme transnational, témoignage, Alicia Kozameh. 


\section{Introduction}

Adopting a transnational approach to feminist translation entails recognizing heterogeneity as its centerpiece. As pointed out by Flotow (2009), considering women as a homogenous group results in misrepresentation by certain discourses or texts in translation. She indicates that the multiple differences among women are due to factors including class, race, ethnicity, and ideological affiliation. The question then arises as to how many of those differences can be accounted for in translation, or, in other words, the extent to which translation turns out to be homogenizing and stereotyping when recreating women as a single undiversified group within mainstream patriarchal frameworks. This research proposes a case study that analyzes the English translation of the Argentine testimonial narrative Pasos bajo el agua (1987), Alicia Kozameh's account of the last military dictatorship in Argentina. The article studies how the English translation recreates the literary account of Argentine women political activists and prisoners under a dictatorial regime. ${ }^{2}$ As opposed to the prototypical housewife ${ }^{3}$ expected within the patriarchal system, these militant women are fictionalized as undergoing a double incarceration: not only are they confined to the figurative prison of the female role imposed on them by a patriarchal society in 1970s Argentina, but they are also actually deprived of their freedom by illegal detention. The article examines how the source text con-

2 This paper adopts a discourse-centered approach. Therefore, the translator as an empirical subject is beyond the scope of analysis.

3 Throughout this article, the expressions "housewife" and "militant women" are used, respectively, to refer to how discourse constructs the patriarchal position deemed ideal for women in 1970s Argentina vis-à-vis the new roles assumed by them at the time. The text is by no means engaging in a degrading, binary rhetoric. structs gender and how this is reconstructed in translation, producing (or not) a gender-aware version of this group of women for the target audience. In particular, the analysis explores how gender is inscribed by means of figurative language, specifically through metonymy.

From a literary standpoint, metonymy is defined here as a figure of speech whereby a term is used to convey a whole range of culture-bound associations closely connected with experience. Therefore, metonymies are conceived of as language constructions that express no essence but recreate cultural conventions in discourse (Jakobson, [1957] 1990; de Man, 1979; Eco, 1979; Matzner, 2016). This paper looks into metonymy in translation, since the evocative potential of this figure of speech turns it into a powerful mechanism for repositioning the female subjectivities across borders. The contribution of this work goes beyond Tymoczko's theorization of metonymy in translation studies ([1999] 2014), which she uses for conceptualizing translation at a macro-theoretical level. Instead, through a microanalysis, my study examines how metonymy functions in the translated text from a transnational feminist translation perspective. It is worth noting that apart from Tymoczko's contribution to the study of the metonymic aspects of translation, metonymy has not been much explored in the field of translation studies. ${ }^{4}$

The goal of this paper is twofold. Regarding the question formulated by Castro and Ergun (2017) of "how different forms of texts and

4 Some works on metonymy and translation have been carried out in the fields of cognitive linguistics (Vandepitte \& Hartsuiker, 2011; Brdar \& Brdar Szabó, 2014), literary studies (Godbout, 2014; Matzner, 2016), corpus linguistics (Mol, 2004), and translation studies (Robinson, 1991). 
discourses...migrate and contribute (or fail to contribute) to local and transnational processes of producing feminist knowledges and praxes" (p. 4), this work explores the role of metonymy in the translated text for recreating and reconfiguring a network of complex power relations in the feminist text, thus contributing to "linking geographies of power at various scales (local, national, regional, global) with subject positions (gender/sexual, ethno-racial, class, etc.)" (Alvarez et al., 2014, p. 11). In this connection, the aim is to look into the geopolitics of feminist translation and the power relations established in the translation of an Argentine Spanish-written text into English. This can be revealed by examining the translation of specific metonymies that evoke the incarcerated female condition in an Argentine context. In particular, the analysis includes metonymical categories around three themes that are characteristic of the type of female testimonial narrative under study: activity/passivity, sexuality/asexuality, and expression/silence. To this end, a comparatist methodology is employed to microanalyze excerpts from the source and target texts. Here, a close-reading technique is applied to describe and explain the functioning of particular metonymies so as to offer a more in-depth understanding of these discursive operations and foreground their relevance. An analysis of this kind contributes to exposing how translation recreates women into another (hegemonic) language and culture. Processes of stereotyping and mainstreaming in the translation of figurative language show a tendency to accommodate the feminist text to the patriarchal framework of the target language and culture.

This article consists of three sections: the first section sets up the theoretical framework of the study. The second section provides a contextualization of Kozameh's feminist testimonial and its translation into English. Finally, the third section introduces the microanalysis of the translation of specific excerpts containing metonymic language. In the conclusion, I discuss possible future directions for the research.

\section{Metonymies in and Through Translation}

Identified by Jakobson ([1957] 1990) as a typical strategy in prose, particularly in realist fiction, metonymy - Greek for "change of name" - may be broadly defined as a figure of speech in which a term replaces another with which it is closely associated in experience (Abrams, [1957] 1999). For Jakobson, the metonymic relations rely on semantic contiguity, i.e., spatial and temporal associations connected with experience. The cultural boundedness of metonymy is further underscored by de Man (1979) and Eco (1979), who posit that metonymy is a contingent and arbitrary association resulting from cultural conventions. This sociohistorical dimension of this figure of speech turns it into a language construction that expresses no essence but a cultural construct. In this frame, expressions such as "combat boots" can stand metonymically for men and power, while "a woman's voice" - "in a woman's voice he laughed" (Kozameh, 1996, p. 16) - in contrast, establishes an association with a weak and undesirable trait in relation to women. In the same vein, Matzner (2016) notes that the semantic shifts produced in metonymic relations are pragmatically determined, i.e., the result of language used by a certain culture at a certain time. He stresses that the two elements at work in every metonymy include the present term and an inferred term, which the reader must infer when a literal reading is felt to be impossible in a given context. It is therefore interesting to look into the way in which translation renders the culturally determined associations 
of this trope in another culture and language, and what particular readings are proposed to the target audience.

From a translation studies standpoint, Maria Tymoczko ([1999] 2014) reflects on the metonymic aspects of translation in the context of postcolonial Irish literature. She foregrounds that the metonymies of translation, i.e., the metonymic selection by the translator of specific attributes to recreate or to efface, are loaded with political and ideological assumptions and can serve a resistant agenda. In her words, "the translation metonymically constructs a source text, a literary tradition, a culture, and a people, by picking parts, aspects, and attributes that will stand for wholes" (p. 57) for a target audience by allowing specific aspects of the source text to predominate and represent the whole work. The microanalysis presented in this article seeks to show that metonymy is significant for translation not only as a useful notion for conceptualizing translation at a macro-theoretical level. The examination of the translation of actual metonymies proposed here will also exhibit the political and ideological implications evident in various translation and selection strategies, stressing the importance of this culturally loaded trope for the dissemination of feminist epistemologies across boundaries.

In Pasos bajo el agua (Kozameh, 1987), the use of figurative language works as a locus of feminist praxis. Metonymy plays a significant role in the constitution of the feminist source text since it is a significant discursive mechanism that contributes to foregrounding gender issues in regard to the incarcerated female self. Such rhetoric in the source text imposes specific challenges on translation. Given that translation is an "important means of producing identities, knowledges and cross-cultural encounters" (Castro \& Ergun, 2017, p. 1), the translation of metonymic language may —or may notcontribute to transnational cultural exchanges in the pursuit of feminist justice and alliances (Alvarez, 2014). By analyzing the translations of metonymic mechanisms in the feminist text, it is possible to show the cross-border transit of gendered relations and the status of political activist women in a patriarchal society -in this case, 1970s Argentina. Furthermore, in terms of the geopolitics of translation, the issue arises around the way in which feminist practices and agendas travel across borders via translation in a hierarchically organized world (Castro \& Ergun, 2017). Since power asymmetries among regions, cultures, and languages call for a counter-practice of translation, which disrupts the hegemonic discourses about gender and feminism (Costa, 2014), the examination of the use of metonymic language from a transnational feminist translation studies standpoint raises two relevant questions: How does translation work at reconfiguring the female subjectivity of an Argentine political activist and prisoner for a new audience through figurative meaning? How is the Argentine Spanish-written feminist text recreated for a hegemonic Anglophone culture?

\section{Alicia Kozameh's Testimonial of the Militarized Space}

Alicia Kozameh has published seven novels - some of which have been translated into English, French, German, and Italian - a collection of short stories, and a book of poetry, as well as two anthologies and a book written in collaboration with other fellow former political prisoners from the last military dictatorship in Argentina. Born in 1953 in Rosario, ${ }^{5}$ young Alicia Kozameh became a militant in the

5 Capital city of the province of Santa Fe, in northeastern Argentina. 
Workers' Revolutionary Party. ${ }^{6}$ As a result of her militant activities, in 1975 she was detained and was held captive for three years in different detention centers (Bolognese, 2013). After her release in 1978, she was exiled in California and later in Mexico. She returned to Argentina in 1984 just after the fall of the dictatorship and published the first edition of Pasos bajo el agua. ${ }^{7}$ Due to the several threats she received as a result of her literary testimony, she decided to return to the United States (Portela, 2013; Pfeiffer, 2016). Since 1988, she has lived in Los Angeles, where she is a professor in the Creative Writing Program in the Department of English at Chapman University.

Kozameh's testimonial text Pasos bajo el agua is a feminizing account - both in terms of content and style - of her experience of being incarcerated as a political prisoner in a military detention center (from 1975 to 1978) and as an exile in Mexico and in the United States. Framed within a hierarchical and male-controlled dictatorial regime, Sara, the main character, embodies the young political activist who is illegally detained by the military forces. Female subordination is narrativized in Kozameh's text in terms of female submission, sex-based gender relations, and the imposition of silence. Strategically used to convey a message of resistance, here the evocative power of figurative language turns the unsaid into a central element of discourse and appeals to an active audience capable of reading between the lines and "hearing" the imposed silence (Davidovich, 2014, p. 157). As Pfeiffer (2008) explains, the author narrates history - in which a female autonomous subjectivity is not expected - from a female perspective in order to state the cruelties of

6 Partido Revolucionario de los Trabajadores.

7 A second - and last - edition was published by the publishing house Alción in the province of Córdoba in 2002. man-controlled social order without explicitly pronouncing it. Kozameh's text expresses the female voice, which patriarchal society and the discourse of the military dictatorship expect to remain silent and subordinate to men. The literary work advances a female critique that defies the male order by making gender inequalities visible and voicing what used to be silent (Libânio, 2013). In Pasos bajo el agua, the author gives voice to all women agonizing in military detention centers in Argentina and in exile and exposes the violence exerted by the State to control these women who are considered subversive. Kozameh's testimonial fictionalizes Argentine activists' plights and persecutions in the patriarchal system and the power relations between the tortured female body and the discourse of the regime (Buchanan, 2005). Through literature, Kozameh appropriates mainstream discourse and develops her own type of writing, thus managing to relocate herself as a subject - rather than an object- of discourse. In so doing, she advances a feminine narrative, which is representative of the collective female experience of women under the Argentinean dictatorial regime (Libânio, 2008, 2013).

In Pasos bajo el agua, Kozameh constructs alternative female subjectivities, challenging and destabilizing the notion of a single and stable memory and identity (Davidovich, 2014). In effect, the solidarity forged among the women political prisoners in the narrative helps them to resist their captors' goal, namely, to destroy them psychologically and reduce them to subjugated and submissive bodies (Goldberg, 2013; Portela, 2013). The resistant female subjectivity resorts to an intense intellectual and creative activity. Classes are given, films and books are retold, poems are written and hidden, and a whole clandestine library is kept and carried in the prisoners' bodies (Tomkins, 2005; Bolognese, 2013). Discursively, the 
female experience is foregrounded in the text by a specific rhetoric, which underscores power asymmetries and raises questions of nation, race, sexuality, class, and gender (DeRocher, 2018). In this context, metonymy stands out as a conspicuous trope in the testimonial text, since it is through single words or expressions that the text manages to recreate women's status and a whole network of gender-based power relations.

\section{Pasos that Become Steps}

Pasos bajo el agua was translated into English by us translator David E. Davis, who specializes in Argentine and Chilean vanguard literature and Latin American crime fiction. It was published as Steps Under Water: A Novel in 1996 by the University of California Press. Since then, it has been included as course materials in numerous universities in the United States. The book lacks re-translations or re-editions, making it the only rendering for an Anglophone audience. Because of specific changes introduced to the English version, the translation may be said to intensify the fictional nature over the documentary aspect of Kozameh's text. Indeed, there is a significant subtitle, not present in the Spanish text, "A Novel," which stresses the importance of the creative process and distances the source text from its testimonial nature and the historical events it recreates (Breckenridge, 2013). Furthermore, some paratextual elements - the drawings Kozameh kept in her diary while incarcerated and the official permit allowing her to keep the diary - have been eliminated. For Breckenridge (2013), factors such as geographical and temporal distance may account for these editorial decisions. The Anglophone audience is perhaps expected to be less acquainted - or personally involved or even interested- with the sociohistorical events vis-à-vis the Argentine or Spanish-speaking audience.
The following section examines how the English translation recreates the network of gender-based power relations that are present in the source text through the use of metonymic language and the geopolitical aspects. Following Pfeiffer (2005), ${ }^{8}$ the analysis focuses on three categories, which are pervasive in the literary work. There is a close look at how gender is constructed in the source and target texts around the themes of female activity versus passivity, sexuality vs. asexuality, and expression vs. silence.

\subsection{Female Selves Resisting Passivity}

Pasos bajo el agua evidences the tension between the patriarchal intent to subdue militant women, who transgress and challenge the prevailing male-based status quo and their resistant and surreptitious mechanisms for remaining active. In this context, the activist female figure is depicted as far from passively accepting the submission imposed on her. The testimonial shows the steadfast determination of the militant to be active in the context of oppression and the constantly looming threat of death. The narrator makes explicit that for Sara, the main character, "[l] inactividad le provoca llanto" (inactivity makes her want to cry) (Kozameh, 1987, p. 53). ${ }^{9}$ Further, activity and inactivity are associated in the narrative with two different female roles: the seditious and mutinous woman activist vis-

8 Pfeiffer employs these categories to stress the differences between the two main characters in Patas de avestruz (2003), another novel by Kozameh. Here, Pfeiffer's analysis is extended, and the categories are applied to the study of Pasos bajo el agua and its translation because they stand out as prominent themes in the texts.

9 It is worth noting that the English translation "[s]tanding around makes her want to cry" (Kozameh, 1996, p. 44) eliminates the noun "inactividad" (inactivity), which evokes a relevant theme in the narration. In this sense, the translation lacks the expressive force of the source Spanish noun. 
$\grave{a}$-vis the acquiescent and submissive housewife - the role that patriarchal society deems natural for women. Discursively, these associations are materialized through metonymic language.
In Examples 1-3 below, it can be observed that the source gendered metonymic allusions are, to a greater or lesser extent, literally recreated in the translation.

\section{Examples 1-3.}

Amigas: no la que podrías haber conocido ayer en tu ida al supermercado, ${ }^{*}$ y que te preguntó el precio de la lechuga porque no estaba claro en el estante. No, no, Sara. No. Las otras. Esas mujeres que vos y yo también somos. Ésas a las que las circunstancias de la vida - que no son abstracciones - les mostraron sucesivamente que el mundo necesitaba gente dispuesta a poner su cuerpo, su tiempo, su eternidad, para intentar el fortalecimiento de la vida de los seres humanos. Esas mujeres. Las que definieron a su enemigo. Las que se concentraron en la lucha. Ésas a las que ese enemigo, ganándoles una batalla, tiene físicamente en sus manos (Kozameh, 1987, p. 52).

- Mary, pedile la plancha a la celadora... Lo cotidiano. Se arreglan para las visitas...Se despertó cuando Adriana, con la plancha en la mano, la movió con suavidad inesperada, la hizo levantarse y la condujo al baño donde se encerró con ella sin ningún sonido, y con un cuchillo a modo de destornillador desmontó cada tuerca. Era la primera vez que Sara veía una plancha por dentro. Observó maravillada como, con dedos cirujanos, Adriana extraía papeles minúsculos doblados y vueltos a doblar y se los iba entregando (Kozameh, 1987, pp. 35-36).

A ver si un día de éstos nos das a los que te queremos el sano privilegio de ser los primeros en saber que has abandonado eso que llamamos manija en el más venerable tono metropolitano y patriótico. No es que me moleste... que remuevas el guiso, pero vos sabés que soy más bien sensible y prefiero, en vez de darle al cucharón, ponerle la tapa a la olla (Kozameh, 1987, p. 139).
Friend: not the one you might have bumped into yesterday on the way to the market, the one who asked you the price of the lettuce because it wasn't clearly marked on the shelf. No, no, Sara. No. Those other women. You and I are those women too. Repeatedly shown by life's circumstances - which are not abstractions-that the world needs people willing to put forth their bodies, their time, their eternal existence, to try to strengthen human life. Those women. Who defined their enemy. Who concentrated on the fight. Women whom that enemy, having won the battle, physically holds in its grip (Kozameh, 1996, p. 42).

"María, ask the guard for the iron..." The daily routine. They get all dolled up for the visitors... She woke when Adriana, iron in hand, roused her with a surprising gentleness, made her get up, and took her to the bathroom where she locked them both in without a sound and, using a knife as a screwdriver, took the iron apart. It was the first time Sara had seen the inside of an iron. She marveled at how Adriana, with the fingers of a surgeon, extracted tiny pieces of paper that had been folded over several times, handing them to her (Kozameh, 1996, pp. 26-27).

Let's see if one of these days you'll give those of us who love you the hearty privilege of being the first to find out you've done away with that tendency of yours, as we would call it, to get all wound up in the most venerable metropolitan and patriotic tone. It's not that it bothers me... that you stir the pot, but you know I'm rather sensitive and would prefer, instead of stirring it, to put a lid on it (Kozameh, 1996, p. 131).

\footnotetext{
* Underlining in all the excerpts has been added for the analysis.
} 
In Example 1, Cristina, a former inmate and friend of Sara's, is recalling and reflecting on their militant experience and on the solidarity developed through their prison years. The translation renders literally the explicit dichotomy between the two women roles suggested in the source text, i.e., the housewife vs. the political activist. In effect, the term "supermercado" (supermarket) and the phrase "precio de la lechuga" (lettuce price), which evoke metonymically the typical housekeeping chores, are translated as "market" and "price of the lettuce," respectively. Likewise, the active political actions referred to in the expressions "circunstancias de la vida," "poner su cuerpo, su tiempo, su eternidad" are recreated literally as "life's circumstances" and "put forth their bodies, their time, their eternal existence," respectively. Interestingly, in the pursuit of literalness, this translation removes a nuance of meaning in the expression "poner el cuerpo," which in Spanish suggests risking one's life. Further in Example 1 , the male-based dictatorship and its illegal methods of repression and incarceration, implied in the metonymies "enemigo" and "tiene fisicamente en sus manos" in the source text, are rendered literally as the "enemy" and "physically holds in its grip." Example 2 is an excerpt from Sara's first day in prison, in which the inmates introduce her into one of the routine subversive mechanisms put in place by inmates for survival: message exchanges through the iron. ${ }^{10}$ The iron is another element that is recreated in the translation and that works metonymically to stress the opposition of this appliance, usually associated with the household chores performed by housewives, and its use as a subversive mechanism of resistance by these political prisoners. In both examples, the metonymic relations

10 Inmates use the iron to send hidden messages back and forth among themselves. recreating the 1970s Argentine female figures make an easy transit into the target language and culture. This may be accounted for by the fact that the translation of figurative meaning in these examples involves more easily recognizable images for an Anglophone reader, as it is less dependent on locally-determined associations.

In Example 3, an extract from Sara's sister's letter from Aubervilliers a couple of years after the dictatorship was over, the source text brings to the fore the post-imprisonment dilemma between keeping a fresh memory of the atrocities suffered and leaving the past behind in order to heal. This idea is conveyed through a cooking-related network of figurative relations inscribed in the nouns "manija" (handle), "guiso" (stew), "cucharón" (ladle), "tapa" (lid), and "olla" (pot). The discursive mechanisms operating here become more complex for translation since in the same items both metonymic and metaphoric associations converge. Metonymically, the Spanish expressions can be associated by contiguity to women's role as housewives, which opposes Sara's militant status as a former political prisoner. Thus, this example works intertextually with the foregoing excerpts to reinforce the opposition between the stereotypical and the supposedly seditious roles. Concurrently, certain metaphors are triggered in the same discourse elements. In Argentine Spanish, the noun "manija" (handle) refers

11 Derived from the idiomatic expression "darse mani$j a$ " (to think insistently about a worrying topic) belonging to a variety of Argentine Spanish slang known as lunfardo - the colloquial vocabulary emerged in early $20^{\text {th }}$ century, which combined the language used by Italian immigrants, marginal and criminal groups, and the gaucho jargon (Grayson, 1964; Gottero, 2006; Conde, $2010,2011)$. In terms of the asymmetrical power relationships between source and target cultures, it may be interesting to note that in the translation, this spe- 
metaphorically to an incessant obsession with one's own concerns. ${ }^{12}$ Likewise, the expressions "remuevas el guiso" (stir the stew) and "darle al cucharón" (stir with the ladle) are metaphors alluding to the recollection of past events and "ponerle la tapa a la olla" (put a lid on the pot) for their obliteration. The translation oscillates between recreating the source text tropes and more target-oriented versions that advance a less complex reading for the receiving audience. The noun "manija" (handle) in the source text has been expanded to the description "tendency of yours...to get all wound up." Here, the gendered associations of figurative language are effaced and meaning is displaced. The English translation resorts to a gender-neutral explanation of a state of worry, nervousness, or anger, which does not recover the full meaning potential of the typically Argentine colloquial expression "manija." Likewise, "remuevas el guiso" (stir the stew), "darle al cucharón" (stir with the ladle), and "ponerle la tapa a la olla" (put a lid on the pot) metonymically suggest women's expected and imposed place in the kitchen as cooking housewives. The first two expressions refer metaphorically to the character's unrestrainable propensity to bring the past to the present, and the last one to leave the past behind. The metonymic associations conveyed in Spanish through the images of the stew, the ladle, and the pot are merged into one figure of speech in English: the pot. Even though this downplays the evocative force of the source text, the target text manages to retain the metaphoric meaning of these expressions. With "stir the pot" and "stirring it," respectively, the target text conveys the notion of unrest -in this case,

cifically Argentine expression is domesticated (Venuti, 1995) and translated by means of the target-oriented explanation "to get all wound up."

12 Definition by the Real Academia Española online. aroused by past memories - as opposed to the intent to "put a lid on it" in order to prevent past suffering from disturbing a life regained after imprisonment. It is conspicuous that recreating the heavy load of figurative meaning in this example presents an enormous challenge to translation. In this case, the target text seems to privilege metaphoric over metonymic meaning, thereby providing a more gender-neutral version. The loss of associations in the metonymic network impacts how women and gender inequalities are portrayed, though. In this case, the gender bias engrained in discourse becomes more patent in the source text, for the metonymic load is heavier. Therefore, the fact that metonymy makes it possible to foreground power asymmetries that are culturally entrenched in discourse calls for careful consideration in terms of the transnational exchange that translation engages in.

\section{2. (A)sexual Bodies}

This section focuses on the analytical category of sexuality to observe how translation, "as a site of production of genders and sexualities" (Bassi, 2017, p. 235), contributes to transnational South-North dissemination of gender knowledge. The way in which sexuality is inscribed in the translation in connection to the female political activist and prisoner reveals the intersection of mainstream gendered relations, sexuality, and male normativity. In the examples below, it can be seen that the translation of metonymic language mostly reinforces male-based stereotypes, acting as a "collaborator in the further construction of sexual and gender normativity" (Larkosh, 2011, p. 9) and advances a less sympathetic reading of women for the Anglophone audience.

Example 4 narrates the journey made by prisoners in a military flight from the detention 
Examples 4-5.

Yo ya estaba en el avión militar, amordazada de pies y tuétanos. Bonavena despenado: imaginate (Kozameh, 1987, p. 25).

Pero mirá las ratas: todavía quedan... Una para cada aterida zona sexual" (Kozameh, 1987, p. 110).
I was already in the military plane, bound from head to toe. Bonavena, our heavyweight champ, castrated. Imagine that (Kozameh, 1996, p. 94).

But look at the rats; there are still some...One for each frigid erogenous zone (Kozameh, 1996, p. 104).

* In italics in the source text.

center to freedom. In these last moments of illegal deprivation of liberty, Sara accounts for her perceptions and feelings of dread. To do so, the source text refers to Sara's sexuality by means of the adjective "despenado" (depenised ${ }^{13}$ ), a coined word meaning having the penis removed. ${ }^{14}$ Here, the character describes her status through a male-related expression. In this example, the phallic allusion, usually associated with male strength and courage, ${ }^{15}$ metonymically suggests the character's impotence and fear at being held by her captors. The political activist is recreated in the narrative with a masculine trait. This is a marked association in a patriarchal society in which it is men who own the phallus, i.e., power. The translation "castrated" proposes a less evocative version in this respect, as well as a less creative mechanism when employing an existing word in the language in lieu of a coinage. Besides, while "castrated" appears as a forceful rendering and manages to recreate part of the meaning of "despenado" - i.e., the removal of

13 Like in Spanish, a term coined from the existing particles "de-," "penis, " and "-ed."

14 The word is formed by combining the negative prefix "des-" ("de-"), the noun "pene" (penis), and the past participle "-ado" ("-ed") in Spanish.

15 In this case, this is reinforced by the reference to the well-known Argentine heavyweight boxer Ringo Bonavena. sexual organs - the phallic reference in connection to the female figure is also significant for the construction of gender relations in the source text. Indeed, the Spanish text relocates male-related meaning into a feminine terrain, offering a more gender-aware version and imposing more interpretative demands on Spanish readers. It can be seen that metonymic language contributes to inscribing new women-centered epistemologies that break with patriarchal mainstream expectations in the source language and culture. This poses a particular challenge to translation in order to advance a feminist agenda and adopt a gender-aware approach to the translation of the feminist text.

Example 5 presents Sara's thoughts during an incident involving other inmates and their children while in prison. The text also refers explicitly to sexuality through the expression "aterida zona sexual" (frozen-stiff sexual zone). In the source text, the phrase refers metonymically to the status of imprisoned women. In an attempt to subjugate and control the subversive female activists, the regime suppresses their sexuality, which becomes "aterida," i.e., paralyzed by the extreme cold of the long incarceration in the isolated basement conditions in which the prisoners are confined. Female subjection and oppression are attained by reducing women into asexual bodies. The 
Examples 6-8.

—Qué te pasa. Estás muy rompebolas.

-Me tiene que venir la menstruación. Disculpe, Majestad (Kozameh, 1987, p. 108).

- ¡Pero qué te pasa hoy! ¡La persecuta te vino, no la menstruación! (Kozameh, 1987, p. 109).

—QQué fue eso?

-Marta está dándole la teta al Curi (Kozameh, 1987, p. 109).
"What's wrong? You're being a real pain in the ass."

"Must be that time of the month coming up. Forgive me, Your Majesty" (Kozameh, 1996, p. 100).

"What the hell's wrong with you today anyway? Don't take it out on me that you're getting your period!!" (Kozameh, 1996, p. 102).

"What was that?

"Marta's breast-feeding Curi" (Kozameh, 1996, p. 102). translation "frigid erogenous zone" relocates metonymic associations into a more stereotypical domain. In effect, "frigid" not only suggests intense cold but also the female incapacity to achieve an orgasm during sexual relations. In this respect, the adjective, used only for women and most often used in derogatory terms,${ }^{16}$ epitomizes the female position of inferiority vs. male sexual potency. Similarly, the term "erogenous" in the translation introduces an idea that is not present in the source text, that of being sexually excited. Both "frigid" and "erogenous" recreate defective — sexually impaired-and passive - requiring a manly stimulus - femininity, respectively. Therefore, displacements in metonymic language, which in the source text evoke the reduction of women to asexual bodies as a typical mechanism of control by the totalitarian regime, may be relocated in a more mainstream patriarchal discourse in translation. This further stresses the importance of metonymic language in regard to how women are recreated - and maybe stereotyped - for the receiving hegemonic Anglophone culture. Thus, translation practices can benefit from the gendered range

16 Cf. https://www.britannica.com/science/frigidity of meanings that can be introduced through metonymy in order to produce a real SouthNorth cross-cultural encounter.

Examples 6-8 include dialogues between Sara and her fellow inmates that reveal their daily lives in prison. In all of them, there are sexually-based metonymic associations, which the target text reconfigures through less ostensibly sexual discourse. A case in point is the translation of the noun "menstruación" (menstruation) in Examples 6 and 7 above. In Example 6, the Spanish "menstruación" is used ironically to refer metonymically to the stereotypical behavior this biological cycle is associated with: "estás muy rompebolas" (being a real pain in the ass). With this ironic response, the character seeks to fight off her fellow inmate's harassment in order to conceal her uneasiness at the risk of being robbed of her baby. ${ }^{17}$ This interpretation is further guided by Example 7, where the irony is made patent and the text exposes that the character's feeling of anxiety and distrust is not

17 During the last Argentine dictatorship, a systematic plan was engineered to steal the babies born in captivity. This topic exceeds the scope of this article. For more, see Arditti (1999), Regueiro (2010), and Bystrom \& Werth (2013), among others. 
due to menstruation. Whereas the Spanish text is explicit in the use of the noun "menstruación," the translated excerpts avoid mentioning it. Menstruation is rendered as "that time of the month" and "period." Although metonymic of the female figure, these translations avoid the explicit and blunt Spanish reference. In this way, the target text presents a less open and perhaps more acceptable rendering of menstruation for the receiving audience, censoring the reference to a part of women's sexuality. On the other hand, the translation of "persecuta" (feeling persecuted) in Example 7 as "[d]on't take it out on me" reinforces the stereotype of bad temper supposedly provoked by menstruation. However, the noun "persecuta" refers to a paranoid feeling of persecution, not connected to the metonymic associations of menstruation. It can be noted that whereas the source text cancels the stereotype suggested in Example 6, the translation stresses it. Further, in Example 8, the expression "dándole la teta" (literally "giving it the tit") refers to another biological function of women and is metonymic of the female role as a nurturing mother. The presence of the word "teta" (tit) in Spanish makes the phrase more sexual than its counterpart verb "amamantar" (breastfeed) — stemming from "mama" (breast). Translated as "breast-feeding," the English expression reduces the sexual load of the source text and may, therefore, be considered more politically correct. Sexually-related metonyms in the testimonial are consistent with the whole narration texture, which places (a)sexuality at the crossroads of male-exerted violence and female resistance in the context of the patriarchal dictatorial regime. Awareness of this subversive power of the source rhetorical mechanisms contributes to reconfiguring meaning in less stereotypical terms in translation so as to favor the recognition by the receiving audience of gender patterns other than those accommodating to mainstream society's expectations.

\section{Examples 9-10.}

¿Dónde está tu hermana infeliz? (Kozameh, 1987, p. 24).

El tipo no alcanza a encender el fósforo: ¡Bajá esa cabeza que tenés, idiota! (Kozameh, 1987, p. 25).
Where's your sister, you sorry-assed bitch? (Kozameh, 1996, p. 13).

The guy doesn't quite strike the match: Put your head back down, cunt! (Kozameh, 1996, p. 15).
Examples 9-10 recreate the way in which Sara is mistreated and denigrated by her male captors when she is illegally detained in her house and then transported to the detention center. In Spanish, the main character is insulted by means of the adjectives "infeliz" (unhappy) and "idiota" (idiot). Neither of these epithets in Spanish applies to women in particular nor are they sexually charged. As opposed to the source text, the translation recreates the female degraded status through the sexually-based expressions "sorry-assed bitch" and "cunt." The English "sorry-assed bitch," entails offensive treatment by means of the term "bitch." Currently used in both American and British English as a personal insult, "bitch" was first applied to "a promiscuous or sensual woman, a metaphorical extension of the behavior of a bitch in heat" (Hughes, [2006] 2015, p. 24). The noun "cunt," an obscene way of referring to the female genital organs, operates metonymically in a similar way. Both translations evoke a 
state of denigration under the male-controlled regime by relying on women's sexuality. The new metonymic associations activated in the translation help to foreground the sexually denigrated position women are in. By adding its own metonymic associations, the translation re-expresses figurative meaning in more sexually-related terms for the target readers and renders gendered discourse more forceful. This example underscores the potential of metonymic language both for recreating the gender relations present in the source text as well as for introducing new associations. Metonymy stands out not only as a recreation strategy in translation but also as a mechanism of intervention that may be employed in the pursuit of a transnational feminist agenda.

\subsection{Silently Resisting Voices}

This section looks into the translation of culturally-bound metonyms of silence. The imposition of silence on women in 1970s Argentine society is a pervasive theme in Pasos bajo el agua. The narration foregrounds that Sara, the main character, has been expected to remain silent since very young. As young as five, her own mother already strove to prevent her from speaking: "Pero nena, callate, callate, dejá de hacer preguntas...Cerrá la boca" (Kozameh, 1987, p. 29) ("Come on now, shut up, shut up, stop asking questions...Shut your mouth!" [Kozameh, 1996, pp. 18-19). For Sara, silence would later become a procedure of control and subjugation by the regime, which deprives its opponents of their voice by incarceration or death. Far from accepting this passively, she resists and never relinquishes her female self to male-determined practices and mandates. The examples below evidence how translation re-inscribes silence in the target language.

\section{Examples 11-13.}

Algunos pares de borceguíes también provocaban su propio accidente contra hombros, cabezas; entre las caras que intentaban reajustar su perspectiva captando un ángulo de la totalidad y la solidez sonora de los tacos. Yo ya estaba en el avión militar, amordazada de pies y tuétanos (Kozameh, 1987, p. 25).

Mientras el auto entraba en la Jefatura de Policía el que manejaba le dijo que ya que estaba tan desconsolada, y que como él era piadoso y no se alimentaba de odio como ella y todos los hijos de puta como ella, y hacía voz de mujer, se reía, o jugaba al marica, iba a comunicarle que su dulce Hugo estaba vivo... (Kozameh, 1987, p. 26).
Some combat boots also unleashed their own form of expression, against our shoulders, our heads, among the faces that tried to readjust their perspective, capturing an angle of the whole and the resounding hardness of the heels. I was already in the military plane, bound from head to toe (Kozameh, 1996, p. 94).

As the car pulled into the police station the driver told her that since she was so broken up, and considering that he was compassionate and didn't feed on hate like her and all the motherfuckers like her, he was going to inform her-and in a woman's voice he laughed, or vamped - that sweet Hugo was alive... (Kozameh, 1996, pp. 16-17). 
Recuerde que goza usted de algunos privilegios: buena cara, buen humor. Aprovéchelos. Cerebro titilante y alerta. Explótelo... No se encapriche con y contra el silencio. Hable y no hable. Escuche y no dé pelota. Ríase y no se ría. Y no joda...Eso me decía a mí misma....a modo de regreso (Kozameh, 1987, p. 154).
Remember that you enjoy certain privileges: a nice face, a good sense of humor. Take advantage of them. A lively and alert brain. Exploit it... Don't get caught up in the silence, or against it. Speak and don't speak. Listen and blow off whatever it is you don't want to hear. Laugh and don't laugh. And don't screw around. That's what I told myself...on my way back (Kozameh, 1996, pp. 148-149).
Example 11 describes Sara's experience during her flight back to freedom in a military airplane. Silence-related figurative meaning becomes prominent in the excerpt. In the source text, gendered power relations are made overt by the use of certain elements that refer by contiguity to men's position of dominance and women's subjugated status. Both "pares de borceguies" (pairs of boots) and "tacos" (heels) refer metonymically to members of the military force. In this context, the sole presence of the noun "borcegui" (military boots) evokes a military officer to the Spanish-speaking reader, since the term is used in Argentina to refer to the typical military footwear (Mouton \& Grijelmo, 2011). The translation "combat boots" turns the source text more explicit, with "combat" indicating the military connection of the phrase. The interpretative demand on English-speaking readers is less stringent since the metonymic relation is made explicit in unequivocal terms. In the same vein, the source verb phrase "provocaban su propio accidente" (provoked their own accident) recreates men treading upon women's shoulders and heads while prisoners are chained to the metal floor of the airplane that will transport them to the detention center Villa Devoto in Buenos Aires. The translation into English "unleashed their own form of expression" relocates the source metonymy into the domain of expression, i.e., men can express violently against women while women must endure military brutality silently. The translation seems to advance a more male-centered interpretation of the source text. On the other hand, the metonyms "hombros" (shoulders), "cabezas" (heads), and "caras" (faces) recreate women as dismembered female bodies. In Spanish, the lack of articles or possessive adjectives preceding these nouns accentuates the dehumanizing effect of male-exerted violence against women. Indeed, these metonymies recreate how, from the male perspective, the prisoners are mere bodies lacking voice and volition. This shade of meaning is not patent in the translation "our shoulders, our heads," because the possessive adjective ("our") restores the human subject to the phrase. Later in the example, Sara's impossibility to express herself is conveyed through the metonymic expression "amordazada de pies y tuétanos" (gagged from feet to marrow). In Spanish, "amordazada" - like the English "gagged"- refers to preventing speech by applying a piece of cloth around one's mouth. In this figure of speech, a marked collocation with "pies" (feet) and "tuétanos" (marrow) is observed. In this way, in the source text, three different ideas converge in the same metonymy: the imposition of silence ("amordazada" [gagged]), the prohibition to move ("pies" [feet]), and the depth 
and intensity of the experience ("tuétanos" $[\text { marrow }]^{18}$ ) from the enunciator's perspective. The target text "bound" does not allude to the impediment to speak. Similarly, the metonymic web of relations conveyed through the images of "feet" and "marrow" is displaced by referring to other parts of the body. The English "bound," "head," and "toe" seem to fall short in recreating the expressive force of the elements that form the Spanish figure of speech. The complexity of metonymy is, thus, further stressed in this example. It can be noted that displacements in the elements composing the trope can, on occasions, advance a slightly different and simplified reading of women's brutal experience for the Anglophone audience. Thus, the challenge faced by translation in terms of feminist practices and strategies is double. In the feminist text, translation needs to recreate metonymic language and its powerful gendered associations as well as retain, to the extent possible, the creative and disruptive play with language operating in the trope. Both the gender issues raised and the way they are inscribed in discourse are prominent to further a feminist agenda across borders.

As stated, some of the metonymic aspects of the source text become particularly relevant for translation with regard to gender. Example 12 exposes the male/military deprecating discourse used against women. As Sara is illegally transported by car to "El Sótano," her captors voice their hatred toward this woman political prisoner with gendered language. The metonym "voz de mujer" (woman's voice) rendered as "in a woman's voice" in the translation, brings attention to the negative associations with the female figure from a patriarchal standpoint. Through the metonym, it becomes

18 Here, "tuétanos" (marrow) refers to the expression "hasta el/los tuétano(s)," which means "deep and intense" in Spanish (see https://dle.rae.es/?id=asXuma1). clear that women are deemed inferior to men. Not only is the woman's voice not supposed to be heard, but it is also a sign of ridicule. Furthermore, the narration metonymically suggests women's inferiority and their underestimation with the expression "jugaba al marica" (acted like a sissy). The Spanish "marica" (sissy) is derogatory for a homosexual man whose gestures and attitudes resemble those of a woman. This expression reinforces the contiguous association of women with negative traits, which are used here to humiliate Sara. In the translation, "vamped" repositions meaning in a female domain by referring to women who try to sexually attract men with deceitful intentions. No trace of homosexuality can be recovered by Anglophone readers. The target text also evokes a deeply-rooted patriarchal system, in which women are accepted to be inferior and men are not expected to be effeminate but strong and masculine. However, it does so by operating its own metonymic mechanisms. Again, this relocation of figurative meaning can serve the translation of the feminist text to convey gendered relations in terms that are perhaps more adjusted to the target audience and maybe less disruptive.

While the military officers can freely express themselves, Sara is unsure about speaking, even after returning home from imprisonment. Example 13 contains the last lines in the narration, i.e., the words Sara tells herself on her way home in her father's car after being released. Certain mainstream stereotypes come to the fore through metonymy in these excerpts, thus showing the imposition of silence Sara endures during and after her experience as a political prisoner. In the source text, the metonymic expressions "una buena cara" (a nice face) and "cerebro titilante y alerta" (twitching and alert brain) show the opposition between the stereotype of women as an object of beauty and intelligence and shrewdness, 
respectively. Sara expresses categorically that she should take advantage of her looks and exploit her brain. In the translation, the first metonymic association to beauty as a female asset is recreated as "a nice face" and the brain/intelligence metonym "cerebro titilante" (twitching brain) as "lively...brain." It seems that the appearance stereotype travels more easily to the target culture than the association connected to women's intelligence, with "lively" evoking activity and enthusiasm, and "titilante" a slight trembling of a part of the body. When it comes to speaking, Sara expresses her hesitancy about expressing herself: "Hable $y$ no hable." This underscores the character's wariness regarding speech and society's expectation that she should remain silent: " $Y$ no joda" (do not cause trouble). In this case, "joder" — "disturb" in this context - is metonymic of the fact that hearing women's voices is presented as disturbingly out of the norm in the narrative. Even though in Spanish "joder" also includes a sexuality-related definition of having sexual intercourse, ${ }^{19}$ in Argentina the word is never used with this meaning but is a vulgar expression for disturbing or annoying. The translation recreates "joder" as "screw around," connected to wasting time unproductively or being sexually promiscuous. Further, the phrase underscores sexuality linked to promiscuity in derogatory terms against women, as opposed to the sexual-neutral associations of the source text. In this case, the translation misses the reference to silence that stems from the peculiarities of the Argentine expression, but it manages to recreate a deprecated female image for the target reader by introducing its own metonymic relations. The analysis stresses the significance of metonymy to reveal the gendered agenda proposed to the hegemonic Anglophone audience.

19 See https://dle.rae.es/?id=MVjNCIs

\section{Concluding remarks}

This article has drawn attention to the prominent role of metonymic language as a discursive mechanism for configuring female subjectivities in this feminist text as well as in its translation. It has been seen that the testimonial narrative studied challenges mainstream patriarchal assumptions in 1970s Argentina by portraying a female militant figure that conflicts with the prevailing woman-as-housewife stereotype prevailing in the patriarchal society of the time. Further, the narrative shows how the male-controlled system strives to punish and discipline these women - deemed as a subversive threat - and how women resist all attempts made at restoring them to the role they are expected to assume. In this context, figurative language contributes to inscribing new women-centered epistemologies in the source text. The analysis of the translated text has enabled us to arrive at three main conclusions. First, the recourse to literality as a translation strategy relies on less culturally entrenched figurative language. The more locally-anchored the meaning of the trope, the more difficult it is for translation to recreate nuanced meaning in its entirety on a one-onone basis. Translation needs to compensate for the impossibility to recreate all the source layers of meaning by means of specific strategies, like glosses or notes in the paratext. In regard to the recreation of power relations, the source text seems to generally offer a more gender-aware reading, which, in turn, places greater interpretative demands on the Spanish-speaking audience. The translation, for its part, sometimes relocates metonymic language in more male-centered terms, apparently more adjusted to the receiving mainstream discourse. On occasions, this might curtail the potential of source metonyms to bring to the fore women's gender issues and hinder the transit of resistant and defying 
female epistemologies into a new (hegemonic) language and culture. However, the relocation of figurative meaning can also create new and enriching metonymic associations that further advance the feminist agenda and can, thus, become an intervention strategy in the translated text. Finally, in and through metonymic language it is possible to recognize heterogeneity among women and the new emerging roles in the Argentine culture.

Exploring the role of metonymy in the translated text can shed light on how the network of complex power relations in feminist texts such as the one under study is recreated and reconfigured for the target audience, i.e., it serves to reveal the cross-border passage of power relations. A trope-based awareness of this kind can contribute to privileging feminist translation strategies and interventions, which, in the words of Castro and Ergun (2017), foster transnational epistemic exchanges, inspire political growth across borders, and facilitate new visions of equality and social justice. As can be seen, the evocative potential of metonymy requires careful attention and consideration in the translation of feminist texts from a transnational perspective. Future research would benefit from an extension of the corpus or analysis so as to delve into the translation of non-Western feminist texts into hegemonic languages other than English, such as French or even Spanish. Additionally, the works of metonymic language could be further explored in the cases of re-translation and self-translation of feminist texts, in order to examine how gender is reconstructed throughout time and in the hands of author-translators.

\section{References}

Abrams, Meyer Howard. ([1957] 1999). A glossary of literary terms $\left(22^{\text {nd }} E d.\right)$. Massachusetts: Heinle \& Heinle.
Alvarez, Sonia E., et al. (2014). Translocalities/translocalidades: Feminist politics of translation in the Latin/a Americas. Durham: Duke University Press. https://doi. org/10.1215/9780822376828

Arditti, Rita. (1999). Searching for life. The grandmothers of the Plaza de Mayo and the disappeared children of Argentina. Berkeley, Los Angeles, \& London: University of California Press.

Bassi, Serena. (2017). Displacing LGBT. Global Englishes, activism and translated sexualities. In Olga Castro \& Emek Ergun (Eds.), Feminist translation studies. Local and transnational perspectives (pp. 235-248). London \& New York: Routledge. https:// doi.org/10.4324/9781315679624-17

Bolognese, Chiara. (2013). Censura carcelaria y liberación por la escritura: el caso de Alicia Kozameh. In Erna Pfeiffer (Ed.), Alicia Kozameh. Ética, estética, y las acrobacias de la palabra escrita (pp.129-143). Pittsburgh: Pittsburgh University.

Brdar, Mario \& Brdar Szabó, Rita. (2014). Metonymies we (don't) translate by. $A r$ gumentum, 10, 232-247. http://argumentum.unideb.hu/2014-anyagok/angol_kotet/brdar_szabo.pdf

Breckenridge, Janis. (2013). El arte de contar: la evolución de Pasos bajo el agua como testimonio ilustrado. In Erna Pfeiffer (Ed.), Alicia Kozameh. Ética, estética, y las acrobacias de la palabra escrita (pp. 59-68). Pittsburgh: Pittsburgh University.

Buchanan, Rhonda Dahl. (2005). El cuerpo tiene la palabra: Pasos bajo el agua de Alicia Kozameh. In Edith Dimo (Ed.), Escribir una generación: la palabra de Alicia Kozameh (pp. 41-50). Córdoba: Alción.

Bystrom, Kerry \& Werth, Brenda. (2013). Stolen children, identity rights, and rhetoric (Argentina, 1983-2012). JAC, 33(3/4), 425-453. https://www.jstor.org/stable/43854562 
Castro, Olga \& Ergun, Emek. (2017). Feminist translation studies. Local and transnational perspectives. London: Routledge. https:// doi.org/10.4324/9781315679624

Conde, Oscar. (2010). Diccionario etimológico del lunfardo. Barcelona: Taurus.

Conde, Oscar. (2011). Lunfardo. Un estudio sobre el habla popular de los argentinos. Barcelona: Taurus.

Costa, Claudia de Lima. (2014). Feminist theories, transnational translations, and cultural mediations. In Sonia E. Alvarez et al. (Eds.), Translocalities/translocalidades (pp. 133-148). Durham: Duke up. https://doi. org/10.1215/9780822376828-008

Davidovich, Karin. (2014). Memorias en femenino: testimonios de mujeres sobrevivientes de la dictadura argentina (Doctoral dissertation). Vanderbilt University. https://etd.library. vanderbilt.edu/available/etd-09192014102046/unrestricted/Davidovich.pdf

De Man, Paul. (1979). Allegories of reading. New Haven \& London: Yale University Press.

DeRocher, Patricia. (2018). Transnational testimonies. The politics of collective knowledge production. Seattle: University of Washington Press. Kindle Edition.

Eco, Umberto. (1979). The role of the reader. Bloomington: Indiana University Press.

Flotow, Luise von. (2009). Gender and sexuality. In Mona Baker and Gabriela Saldanha (Eds.), Routledge encyclopedia of translation studies ( $2^{\text {nd }}$ Ed.). London \& New York: Routledge.

Godbout, Patricia. (2014). Translated figures of speech in Anne Hérbert and Alice Munro. In Donna R. Miller \& Enrico Monti (Eds.), Tradurre figure/translating figurative language (pp. 183-191). Bologna: CESLIC.

Goldberg, Florinda. (2013). "Estar completos donde estamos": identidad y territorio en la narrativa de Alicia Kozameh. In Erna Pfeiffer(Ed.), Alicia Kozameh. Ética, estética, y las acrobacias de la palabra escrita (pp. 2944). Pittsburgh: Pittsburgh University.

Gottero, Laura. (2006). Diccionario de lunfardo. Buenos Aires: Andrómeda.

Grayson, John D. (1964). Lunfardo, Argentina's unknown tongue. Hispania, 47(1), 66-68. https://doi.org/10.2307/337280

Hughes, Geoffrey. ([2006] 2015). Encyclopedia of swearing: The social history of oaths, profanity, foul language, and ethnic slurs in the English-speaking world. London \& New York: Routledge. https://doi. org/10.4324/9781315706412

Jakobson, Roman. ([1957] 1990). Two aspects of language and two types of aphasic disturbances. In Krystyna Pomorska and Stephen. Rudy (Eds.), Language in literature (pp. 115-133). Cambridge, Mass, London: The Belknap Press of Harvard University Press.

Kozameh, Alicia. (1987). Pasos bajo el agua. Buenos Aires: Contrapunto.

Kozameh, Alicia. (1996). Steps under water: A Novel. (David E. Davis, trans.). California: University of California Press.

Kozameh, Alicia. (2003). Patas de avestruz. Córdoba: Alción.

Larkosh, Christopher. (2011). Introduction. In Christopher Larkosh (Ed.), Transcultural practice, gender/sexuality and the politics of alterity (pp. 1-9). London \& New York: Routledge.

Libânio, Ana Luiza. (2008). The autonomous sex: Female body and voice in Alicia Kozameh's writing of resistance (ma thesis). Ohio University. https://etd.ohiolink.edu/!etd.send_ file? accession $=$ ohiou $1212634746 \&$ disposition=inline

Libânio, Ana Luiza. (2013). Linguagem, discurso, escrita feminina-Pasos bajo el agua. In Erna Pfeiffer (Ed.), Alicia Kozameh. Ética, estética, y las acrobacias de la palabra escrita (pp. 97-105). Pittsburgh: Pittsburgh University. 
Matzner, Sebastian. (2016). Rethinking metonymy. Literary theory and poetic practice from Pindar to Jakobson. Oxford: Oxford University Press. https://doi.org/10.1093/ acprof:oso/9780198724278.001.0001

Mol, Susan. (2004). 'Head' and 'heart': Metaphors and metonymies in a cross-linguistic perspective. In Karin Aijmer \& Hilde Hasselgärd (Eds.), Translation and corpora (pp. 87-111). Gothemborg: Acta Universitatis Gothoburgensis.

Mouton, Pilar \& Grijelmo, Álex. (2011). Palabras moribundas. Barcelona: Taurus.

Pfeiffer, Erna. (2005). El cuerpo-texto en Patas de avestruz. In Edith. Dimo (Ed.), Escribir una generación: la palabra de Alicia Kozameh (pp. 53-75). Córdoba: Alción.

Pfeiffer, Erna. (2008). "La historia como memoria personal y elaboración literaria. La escritura de Alicia Kozameh: Pasos bajo el agua (1987/2002)." Destiempos, 3(13). http://www.destiempos.com/n13/ErnaPfeiffer_13.htm

Pfeiffer, Erna. (2016). Exilios fragmentados en Luisa Futoransky y Alicia Kozameh, dos autoras de la diáspora argentina. Kamchatka. Revista de Análisis Cultural, 8, 33-48.

Portela, Edurne. (2013). Los pasos imposibles o el retorno a la libertad. In Erna Pfeiffer (Ed.), Alicia Kozameh. Ética, estética, y las acrobacias de la palabra escrita (pp. 145154). Pittsburgh: Pittsburgh University.
Regueiro, Sabina. (2010). Apropiación de niños durante la última dictadura militar argentina. Tramas burocrático-administrativas y estrategias jurídico-politicas en la construcción de parentescos (Doctoral dissertation). http://repositorio. filo.uba.ar/handle/filodigital/1340

Robinson, Douglas. (1991). The translator's turn. Baltimore \& London: The Johns Hopkins University Press.

Tomkins, Cynthia. (2005). Pasos bajo el agua y "Bosquejo de alturas" de Alicia Kozameh: tortura, resistencia y secuelas. In Edith Dimo (Ed.), Escribir una generación: la palabra de Alicia Kozameh (pp. 13-29). Córdoba: Alción.

Tymoczko, Maria. ([1999] 2014). Translation in a postcolonial context: Early Irish literature in English translation [Kindle Edition]. St. Jerome Publishing Ltd.

Vandepitte, Sonia \& Hartsuiker, Robert. (2011). Metonymic language use as a student translation problem. Towards a controlled psycholinguistic investigation. In Cecilia Alvstad, Adelina Hild \& Elisabet Tiselius (Eds.), Methods and strategies of process research: Integrative approaches in translation studies (pp. 67-92). Amsterdam \& Philadelphia: John Benjamins. https:// doi.org/10.1075/bt1.94.08van

Venuti, Lawrence (1995). The translator's invisibility. London \& New York: Routledge. https://doi.org/10.4324/9780203360064

How to cite this article: Yañez, Gabriela Luisa. (2020). Translating Metonymies of the Incarcerated Female Self in Pasos bajo el agua/Steps Under Water, by Argentine Writer Alicia Kozameh. Mutatis Mutandis. Revista Latinoamericana de Traducción, 13(1), 139-158. DOI: 10.17533/udea.mut. v13n1a07 